Journal of Contemporary Governance and Public Policy

Vol. 1 No. 1, April 2020, 27-40

Available Online at http://journal.ppishk.org/index.php/jcgpp

ISSN (Print): 2722-3981 | ISSN (Online): 2722-3973

\title{
Indonesia Green Economy Implementation Readiness of Greenhouse Gas Emissions Reduction
}

\author{
Andika Raka Dianjaya ${ }^{1 *}$, Pretti Epira ${ }^{2}$ \\ 1,2Department of International Relations, School of Postgraduate Studies, Universitas \\ Muhammadiyah Yogyakarta, Jl. Brawijaya, Bantul, 55183, Yogyakarta Indonesia.
}

Received: 2020-01-27; Accepted: 2020-04-22; Published: 2020-04-30

\begin{abstract}
After Earth Summit in 2012, UNEP proposes a new concept to combating Global warming and Climate Change trough economy activities. This concept called "Green Economy". UNEP as a major actor in environmental global governance give support and encourages countries to implement it. As the result, the green economy becomes a prominent theme for politicians, scientists, activists, and businessmen. Green Economy firmly established as international policy agenda and linkages with sustainable development. Indonesia seems to grasp this opportunity by implementing a green economy to their national policies. The aims of this paper are to know how Indonesia's readiness to implementing the concept of Green Economy. Focusing on greenhouse gas emmision as the case study, author found some worying trends that will create some barrier for implementing this concept.
\end{abstract}

Keywords: Green Economy; UNEP; Environment; Greenhouse Emission; Global Governance

How to Cite: Dianjaya, A. R., \& Epira, P. (2020). Indonesia Green Economy Implementation Readiness of Greenhouse Gas Emissions Reduction. Journal of Contemporary Governance and Public Policy, 1(1), 27-40.

Permalink/D0I: https://doi.org/10.46507/jcgpp.v1i1.5 


\section{Introduction}

Humanity facing with profound environmental crises. Global warming widely knowing as a threat to humanities. As the other environmental's crises potentially threatening the continuity of human life. This include with the depletion of water reserves, ocean acidification, loss of biodiversity and reduction of soil fertility. At the same time, there are social and economic challenges that arise. People want to have decent lives, and poverty is still widespread in many countries. This becomes a dual challenge. First, to pursue economic development and a decent life for the peoples and the second is to keep resources consumption and pollution in the level that not give harm to Earth. This kind of concept renowned as a green economy. For the first time, this concept sounded by Uniter by United Nation Environment Program (UNEP) in Nairobi 1982 (Indarti Komala Dewi, Rachman Kurniawan,et al., 2013). Development should become a medium to preserve environmental protection.

During 1989, the term of Green Economy used for report to the Government of United Kingdom. This report entitled Blueprint for a Green Economy (Pearce, D., Markandya, A., Barbier, 1989). This report purpose to advise the UK Government if there was a consensus definition to the term "sustainable development" and the implications of sustainable development for the measurement of economic progress and the appraisal of projects and policies. On this report, they said that economics can and should give aid of environmental policy, this message extended to global problem such as climate change, ozone depletion, tropical deforestation, and resource loss in the developing world (Allen \& Clouth, 2012).

In October 2008, UNEP launched Green Economy initiative to provide analysis and policy support for investment in green sectors. In April 2009, UNEP commissioned report entitled a Global Green New Deal (GGND). This report proposed a mix of policy actions that will stimulate economic recovery and at the same time will improve the sustainability of the world economy. GGND called on government to allocate a significant shares of stimulus funding to green sectors and to focused on three objectives: (i) economic recovery, (ii) poverty eradication and (iii) reduced carbon emissions and ecosystem degradation (UNEMG, 2011).

In February 2010, Ministers and Heads of Delegation of UNEP attended Global Ministerial Environment Forum in Nusa Dua, Bali. This forum acknowledged the Green Economy concept can significantly address the current challenges and deliver development opportunities and multiple benefit for all nations. During this forum as well, UNEP was asked to become leading role in further defining and promoting the concept and brings Green Economy concept into UN Conference on Sustainable Development in 2012 (Rio+20) (Allen \& Clouth, 2012).

UNEP defines Green Economy as one that results in improved human well-being and social equity, while significantly reducing environmental risk and ecological scarcities. In other words, Green Economy is a low carbon, resourceefficient, and socially inclusive. In a green economy, growth in income and employment are driven by public and private investments that reduce carbon emissions and pollution, enhance energy and resource 
efficiency, and prevent the loss of biodiversity and ecosystem services (UNEP, 2011).

The points of promoting Green Economy for developing countries are new paths to achieve sustainable development. Even though it's really contrary to the facts that happen on developing countries. Mostly the economic activities are coming from industrial sectors that produce pollution.

With this kind of condition, the shifting to the green economy are needed for developing countries. It will lead into economic production, value, stability and long term prosperity (Acharya \& Sequeira, 2012). The needs of clean energy economy are important to achieve green economy. This become basic value for any countries in the world if they want to implementing green economy.

\section{Indonesia Towards Green Economy}

Transition Indonesia to green economy coined in 2007. In December 2007, Indonesia hosted the $13^{\text {th }}$ Conference of the Parties to the United Nations Framework Convention on Climate Change (UNFCC) in Bali. During these events, President of Indonesia launched theNational Action Plan for Climate Change. This action focused on intragovernmental coordination, and other areas of technical assistance, outreach and capacity building. The National Council of Government of Indonesia (GOI) has engaged with external partners and key stakeholders, including Ministry of Finance Indonesia to maintain climate change adaptation and mitigation issues, including low carbon development (The World Bank, 2008).

The key for a transition to a green economy is to enable economic growth and investment while increasing environmental quality and social inclusiveness. The main indicators of economic performance, using such as growth in Gross Domestic Product (GDP) that need to be adjusted into account for pollution, resource depletion, declining ecosystem services and the distributional consequences of natural capital loss to the poor (UNEP, 2011).

The implementation of a national Green Economy strategy in each country can be varied according to it's needs. Indonesia's interest in applying green economy can be reflected by a policy that supporting towards four development goals (pro-growth, pro-jobs, pro-poor, proenvironment). Trough Badan Perencanaan Pembangunan Nasional (Bappenas) / National Development Planning Agency Republic of Indonesia, green economy applied into a program that support SDG. (Bappenas, 2012) mentioned 11 sectors that correlated with Green Economy, they are:

\section{Agriculture}

Agriculture is an important sector in green economy. This sector produces sources needed for food. This sector also provides the most jobs needed for combating unemployment and poverty.

\section{Building}

Buildings are an important part of providing public space, private, office and households. The numbers of buildings increase along with population growth in a country. Buildings also consuming energy, that's why designs for green building are needed to support green economy.

\section{Urban}

In line with the growth of buildings, the development of the 
urban sector is needed as well. Urban development trends, not only demand land for providing spaces for building construction, but also need water. Where is not planed properly, it will cause disrupt the existence and survival it habitants. Urban development also demands an increment of transportation, energy consumption and other infrastructure. In addition, with the growth of middle class. Urban development continues to be demanded.

\section{Energy}

With the growth of world population which is more than 7 billion. The energy demand for both consumption commodities and living facilities continues to increase. This action will encourage to search and use of energy from various sources, such as renewable and nonrenewable energy sources.

\section{Fishery}

As one sources of food and with the increase of the population. It will demand food supply. These sources should be maintained properly by process fishery that suitable for the environment such as maximum sustainable yield and using sustainable fishing methods by restocking efforts and maintenance of marine ecosystems.

\section{Forestry}

In terms of a green economy, the forest becomes an irreplaceable place. In order to maintain the balance of ecosystem and biodiversity within it. Forest seen as guardians of water resources as well have functioned as conservation for flora and fauna. The forest becomes an essential part determining the value of the green economy, including how to formulate carbon commodities that can be transacted in the future.

\section{Manufacturing Industry}

In line with Increase population and living needs, it will drive the needs of the manufacturing industry. In addition, the need for raw materials for the manufacturing industry will be escalated. For sure, it will cause pollution that affects the environment. There is should be a way to develop a manufacturing industry that uses natural resources more efficiently.

\section{Tourism}

So far, tourism aspect should be managed as well. Tourism has opportunities that can be managed as components of green economy. Natures and it's ecosystem become economy sources that needed for actracting tourist.

\section{Transportation}

Transportation becomes a main part of the infrastructure in the green economy. The growth of population and increase of population mobility require huge of number transportation services. For example, tourism and other production sectors require an efficient and clean transportation system. Transportation systems must be managed well and in accordance with environmental ecosystem sustainability.

\section{Waste}

Mostly sector development on the above will have implications for creating waste production. Management and regulation of waste expenditure need to be determined from the beginning. It will help to calculate management costs and usage of natural resources efficiently and economically, especially nonrenewable natural resources. The use of natural resources inefficient will produce large waste that will make pollution for the environment. 


\section{Water}

Nature as both producer and disposal of water that needs to be maintained and protected. Population development and water consumption need to be supported by maintaining good natural resources or springs. Nature has the ability to recycle or maintain water so the amount of good quality of water can be maintained from time to time. Water is a very important aspect fort forming a sustainable green economy.

Eleven aspects above illustrate how each sector is important for the development of green economy. The more important is the integration of all sectors that will form a balance between green ecosystems and sustainability development. Furthermore, to manage and develop all sectors, we need new professions or green jobs in all of the sectors. This will open new opportunities that emergence new sources of income for the People of Indonesia.

Those main sectors should be nurtured and developed for achieving green economy. In the hope of gaining economy which is environmentally-friendly, conserve natural resources, minimize pollution and gas emmision that led into environmental damages.

\section{Research Methods}

This paper using content Qualitative Content Analysis to analyze data that collected trough Library research. Researchers regard content analysis describes a flexible method for analyzing text data (Cavanagh, 1997). The specific type of content analysis approach chosen by the researcher varies with the theoretical and substantive interests of the researcher and the problem being studied (Weber,1990). A more thorough analysis of the ways in which qualitative content analysis can be used would potentially illuminate key issues for researchers to consider in the design of studies purporting to use content analysis and the analytic procedures employed in such studies, thus avoiding a muddling of methods (Morse, 1991).

We using collected data describing the green economy concept on Indonesia. This source comes from the Bappenas repository that has legitimation to implement Green Economy in Indonesia. This data will be compared with UNEP Green Economy Indicators. By using Content Analysis we will understand how Indonesia's arrangement and readiness to implement green economy.

\section{Results and Discussion}

\section{There are several}

Before we proceed into GOI policy for implementing Green Economy, we'll elaborate UNEP Green Economy Indicators. During the 2012 UN Conferences on Sustainable Development/Rio+20. The Heads of State and Government and high-level representatives recognize indicators as being necessary to assess progress towards the achievement of the millennium development goals (in the future it will be sustainable development goals) while taking into account different national circumstances, capacities and levels of development. Green economy has been proposed as national policy development and international cooperation and support for sustainable development. This means UNEP or the UN system will give support to countries that interested in pursuing Green Economy policies by providing methodologies for their evaluation (UNEP, 2014).

An indicator is an instrument that provides an indication that is generally used to describe a condition and/or give an order of magnitude. 
Indicators provide information on a given system's historical and current state and are particularly useful in highlighting trends that can shed light on causal relationships between the elements that make up the system.

The use of indicators is to acknowledge the unique geographical and socio-cultural context in which issues arise and the providing step by step to guide to identify the problem and use the relevant indicator to implementing Green Economy responses. In other words, the concept of manual that UNEP proposes doesn't identify and prioritize global issues to be addressed, but rather provides examples to illustrate what could potentially be considered a challenge in a given context and how to address it. The use of existing indicators across various data sources is encouraged, as well as the involvement of a broad set of stakeholders, to support the design and implementation of a coherent and inclusive green economy strategy. The structure of the manual follows a stylized policymaking process with the following Figure 1:

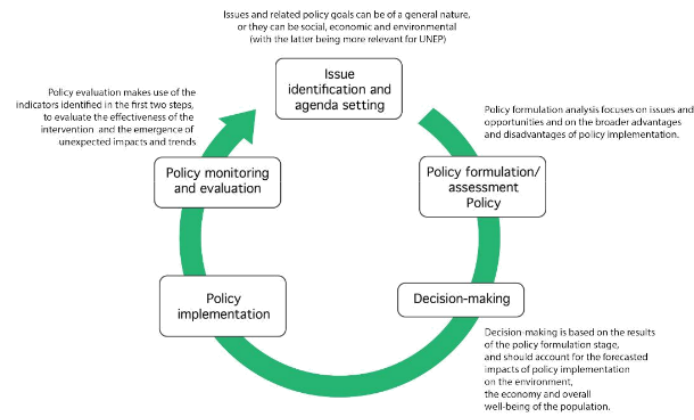

Figure 1 Cycle for integrated policy making process. Source: UNEP, 2014.
The emphasis of the cycle manual above is on stages 1 and 2, and some extent on stage 5 . Given the importance of policy formulation and assessments, and while acknowledging the feedback loops that exist on these points. On stage 3 , decision-making becomes a point in time when a particular policy recommendation is adopted. The decision will be based on a comparison of different policy options that were developed under stage 2. On stage 4 , the role of indicators in policy implementation mainly exercised through monitoring and evaluation from stage 5 .

The manual recognizes that it is never a linear process to make policy. Therefore, it is structured to be easily adaptable to different policy circumstances, including through feedback loops between the related stages when appropriate. Beginning with an issue or opportunity, identified using agenda-setting indicators, policies are described and established using indicators for policy formulation. Indicators of policy evaluation are then used to predict policy impacts. 
Table 1 Overview structure formulation

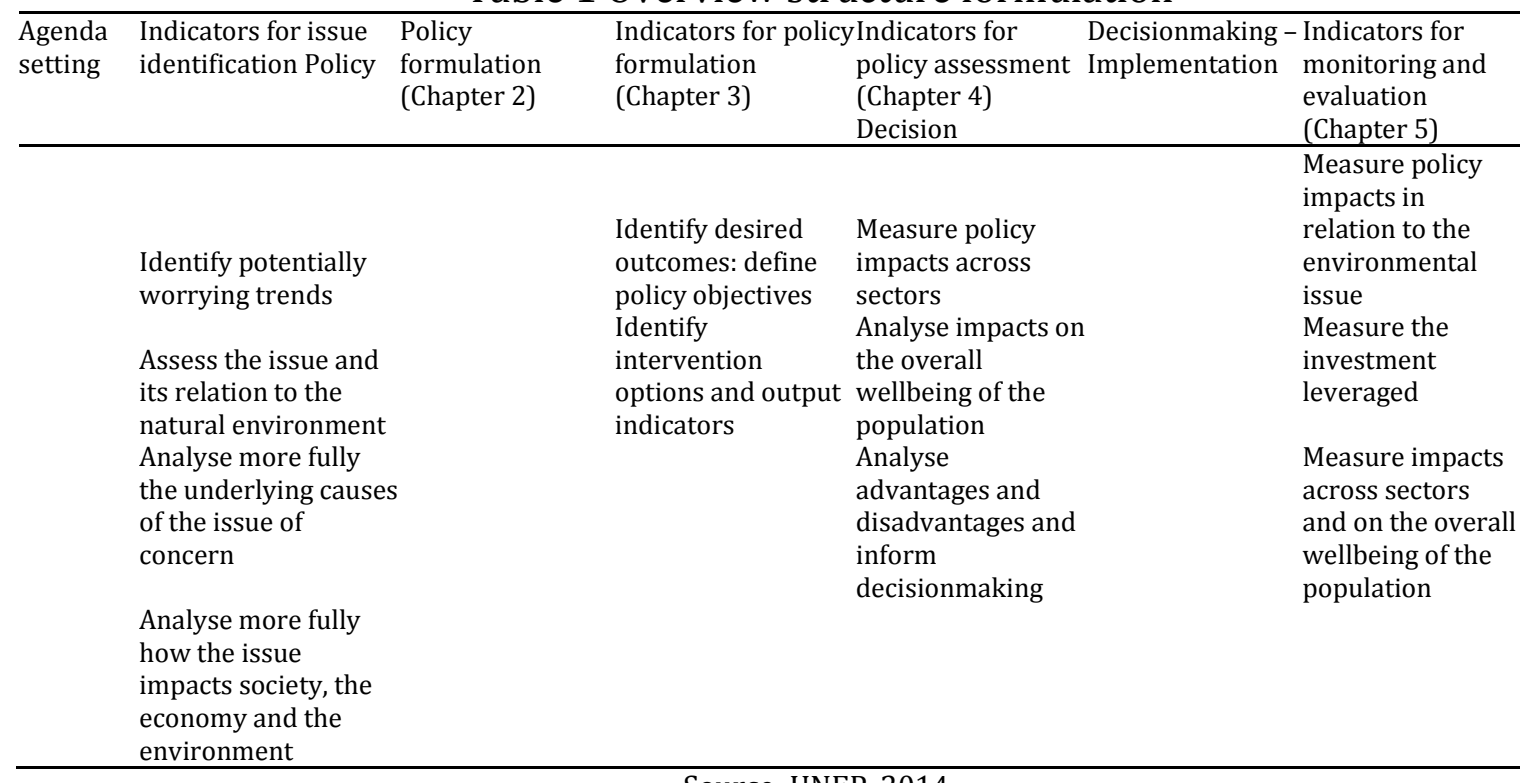

Source: UNEP, 2014.

Table overview structure formulation above can be used for identifying problem on environtmental issues. This indicators helping policy maker to understand scope of problem during policy maker decision. UNEP, which is appointed as the leader of global governance in environmental issues promoting Green Economy policies for environmental purposes (UNEP, 2011). However, the green economy approach not only focusing on environmental only but using the socio-economic approach as well. It means redirect economic investments while taking into account the social implications for both environmental issues identified by governments and the possible policy response on that issue and gaining double or triple wins whenever achievable (UNEP, 2014). The manual should recongnises all three dimensions of sustainable develompent (economic, environmental and social).

By combining cycle for integrated policy-making process and scheme of sustainable development, we can trace entries points for identifying issues and developing green policies. Inline with UNEP's primary mandate, it uses predominantly environmental issues as entry points for a green economy policymaking process using UNEP's examples from four major thematic areas: climate change, ecosystem management, resource efficiency, and chemical and waste. The initial stage of the integrated policymaking cycle consists in identifying the key issues that pose a challenge to sustainable development and that need to be addressed by green economy policies.

The four cross-cutting thematic priorities of UNEP's medium-term strategy were introduced in order to highlight the main environmental challenges presently identified by UNEP at the global level. However, decision makers face social, economic and environmental issues simultaneously, all of which have an impact, to varying degrees, on sustainable development. 
Tabel 2 The four cross-cutting thematic priorities of UNEP's medium-term strategy

\begin{tabular}{|c|c|c|}
\hline $\begin{array}{l}\text { UNEP cross- } \\
\text { cutting thematic } \\
\text { priorities }\end{array}$ & ors & \\
\hline Climate change & $\begin{array}{l}\text { - Country contribution to } \\
\text { anthropogenic climate } \\
\text { change } \\
\text { - Increased } \\
\text { frequency/intensity of storm } \\
\text { surges }\end{array}$ & $\begin{array}{ll}\text { - } & \text { Greenhouse gas emissions (Kt of } \\
& \text { CO2 equivalent/year) } \\
\text { - } & \text { Rainfall (mm/year) and evaporation } \\
\text { - } & \text { Storm-related damages (US\$year) }\end{array}$ \\
\hline $\begin{array}{l}\text { Ecosystem } \\
\text { management }\end{array}$ & $\begin{array}{l}\text { - } \quad \text { Deforestation } \\
\text { - Loss of critical ecosystem } \\
\text { services }\end{array}$ & $\begin{array}{l}\text { - } \quad \text { Forest cover (ha) } \\
\text { - } \quad \text { Extent of land and marine } \\
\text { conservation areas (ha) }\end{array}$ \\
\hline $\begin{array}{l}\text { Resource } \\
\text { efficiency }\end{array}$ & $\begin{array}{l}\text { - Falling groundwater tables } \\
\text { - Low efficiency of non- } \\
\text { renewable energy sources }\end{array}$ & $\begin{array}{l}\text { - Water intensity or productivity } \\
\text { (m3/US\$) } \\
\text { - Coal consumption intensity } \\
\text { (tonnes/GDP) }\end{array}$ \\
\hline $\begin{array}{l}\text { Chemicals and } \\
\text { waste } \\
\text { management } \\
\text { Possible }\end{array}$ & $\begin{array}{l}\text { - Air pollution } \\
\text { - Soil contamination }\end{array}$ & $\begin{array}{ll}\text { - Sulphur oxide (Sox ) emissions } \\
\text { (Kg/yWr) } \\
\text { - } \quad \text { Waste recycling and reuse (\%) } \\
\text { Toxic heavy metal concentration, } \\
\text { e.g., } \mathrm{Hg}, \mathrm{Cd}, \mathrm{Pb}, \mathrm{Cr} .(\mathrm{mg} / \mathrm{kg})\end{array}$ \\
\hline
\end{tabular}

According to UNEP: 2014, in order to build effective policies to address issues above, they should be identified correctly across all related sectors, trough analysis of their cause and effect. In order to develop effective policies to address the above-mentioned problems, they must be correctly identified and explained by careful analysis of their causes and effects across all related sectors:

a. Only with the correct identification of the causes of the issue can policies be designed to have a lasting positive impact.

b. Only with the correct identification of the effects of the issue can policies be designed that maximize synergies and avoid the emergence of negative side effects, in particular in other sectors.

The methodology proposed here provides four main steps in issue identification:

- Identify potentially worrying trends;
- Assess the issue and how it relates to the natural environment;

- Analyse more fully the underlying causes of the issue; and

- Analyse more fully how the issue impacts society, the economy and the environment.

This approach is consistent with the use of the DPSIR framework (UNEP, 2008) through the identification of Drivers (D), Pressures (P), State (S), Impacts (I) and Responses

The four proposed steps are described in this chapter. As regards to policy responses, this will be taken up in Chapter 3 addressing indicators for policy formulation.

If the problem to be analysed is essentially environmental (rather than social or economic), steps 1 and 2 could be merged to move directly to the full analysis of causes and impacts (steps 3 and 4). 
Indonesia Policy on Green Economy

The major implementation Green Economy in Indonesia is the commitment of GOI to reduce greenhouse emissions by $26 \%$ by 2020. This commitment strengthened by Presidential Decree No. 61/2011 focusing Action Plan for Reducing Greenhouse Gas Emissions (RAN
GRK). This action led to another Presidential Decree No. 71/2011 concerning in Inventory for Reducing Greenhouse Gas Emissions.

Using cycle model integration policy from UNEP and sources from E.Murniningtyas: 2014, we can develop policy model for reducing greenhouse emission.

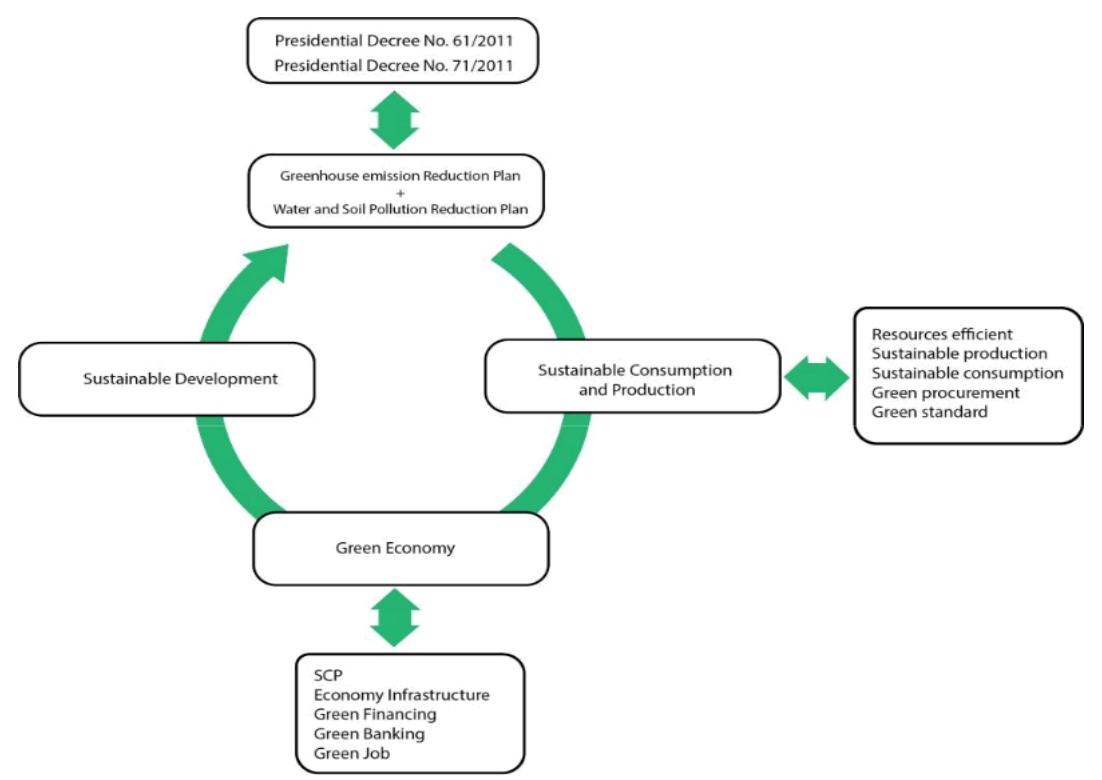

Figure 2 Modification diagram. Source; UNEP, 2014

According to E.Murniningtyas:

2014, water and soil pollution should be monitoring as well. This will help to reduce greenhouse emissions. Ministry who have important roles for monitoring environmental pollution is the Ministry of Environment Forestry, and for monitoring any pollution control and quality improvement would be handled by Environment Agency that works in each region/province in Indonesia. This Environment Agency available for both province and regional area, they work to protect and preserve the environment in their respective areas autonomously.

GOI's policies for using government agencies to perform their agenda shown that they have confidence to accomplish their goals. The ambition for reducing greenhouse emission embroidered on Indonesia National Long-Term Development Plan (RPJPN 2005-
2025). The commitment for pledging to decrease Indonesia's greenhouse gas emissions by 2020 by Former President Susilo Bambang Yudhoyono's and furthered by President Joko Widodo by pledging commitment to a 29 to 41 percents reduction in 2030 (World Resources Institute, 2017). Indonesia also submitted it's first National Determined Contribution to the United Nations Framework Convention on Climate Change (UNFCCC) on 2016. This is a grand leap to Indonesia's goodwill to reduce greenhouse gas emissions. Indonesia allocating a total of USD 55.01 billion for the period 20152019. This funding will increase the implementation of mitigation and adaption actions for the period of 2020-2030 (Republic of Indonesia, 2016).

There are already several policies that implemented by GOI. 
This effort including extending the country's forest moratorium, restoring degraded peatland, implementing energy conservation programs, and pursuing mitigation measures for other sectors and gases (Wijaya, A., H. Chrysolite, M. Ge, et al. 2017).

Using several sectors that mentioned by Bappenas on the
Introduction part earlier. We have total of 11 sectors that cover green economy that inline with SDG. Author will classify those sectors according to Indonesia's goal to reduce greenhouse gas emissions. The table below shown Bappenas plan for reducing greenhouse gas emissions (Bappenas, 2010):

Table 3 Bappenas plan for reducing greenhouse gas emissions

\begin{tabular}{|l|l|l|l|l|}
\hline Sector & \multicolumn{2}{|l|}{$\begin{array}{l}\text { Greenhouse } \\
\text { emission } \\
\text { reduction plan } \\
\text { (gigatons C02) }\end{array}$} & Action Plan & Ministry or Implementation Agency \\
\hline & $26 \%$ & $41 \%$ & & \\
\hline $\begin{array}{l}\text { Forestry and } \\
\text { peatland }\end{array}$ & 0,672 & 1,039 & $\begin{array}{l}\text { control of forest and land fires, management of network and water } \\
\text { systems, forest and land rehabilitation, eradication of illegal logging, } \\
\text { prevention of deforestation, and community empowerment. }\end{array}$ & $\begin{array}{l}\text { Ministry of forestry and environtment, } \\
\text { ministry of agriculture, ministry for public } \\
\text { works and human settlements }\end{array}$ \\
\hline Agriculture & 0,008 & 0,011 & $\begin{array}{l}\text { represent paddy with lowmethane emissions, efficiency water } \\
\text { irrigation, utilization of organic fertilizer }\end{array}$ & $\begin{array}{l}\text { ministry of agriculture, ministry for public } \\
\text { works and human settlements }\end{array}$ \\
\hline $\begin{array}{l}\text { Energy and } \\
\text { Transportation }\end{array}$ & 0,038 & 0,056 & $\begin{array}{l}\text { Utilization of biofuel energy, utilization mas transportation, } \\
\text { improving transport demand management, energy efficiency, } \\
\text { developing renewable energy }\end{array}$ & $\begin{array}{l}\text { ministry for public works and human } \\
\text { settlements, ministry of transportation, } \\
\text { ministry of energy and mineral resources }\end{array}$ \\
\hline $\begin{array}{l}\text { Manufacturing } \\
\text { Industry }\end{array}$ & 0,001 & 0,005 & $\begin{array}{l}\text { Energy efficiency, developing renewable energy } \\
\text { ministry of industry }\end{array}$ \\
\hline Waste & 0,048 & 0,078 & $\begin{array}{l}\text { Construction of landfills, waste management with 3R, utilization } \\
\text { integrated waste water management }\end{array}$ & $\begin{array}{l}\text { ministry for public works and human } \\
\text { settlements }\end{array}$ \\
\hline
\end{tabular}

Source: Bappenas, 2010

There are 5 sectors above that related to green economy and the SDG. These 5 sectors (actually 6 sectors, but Energy and Transportation combined into one sector so it counts as 5 sectors) have a significant impact on the reduction or increase in greenhouse gas emissions. Forestry and peatland will only be examined because this sector contributes the most amount, even when all four sectors are combined.

In the sector Forestry and peatland, there are finding from the World Resources Institute (WRI) in 2017 that potentially become worrying trends. In September 2019, Indonesia experienced forest fires that exceeded the amount during all of 2018. As said by Raffles Panjaitan as a forest fire management acting director at the Ministry of Forestry and Environment, a total of forest fires by the end of September 2019 reached 857,756 hectares $(2.12$ million acres). This total is more than the 529,927 hectares that burned in 2018, according to data from GOI's. The fires have consumed the most land since 2015 (Reuters, 2018). As UNEP's policy formulation. The findings from WRI shown worrying trends. This will led a barrier for implementing green gas reduction.

Forest become irreplaceable place for reducing greenhouse gas emission in Indonesia. Indonesia have problem for handling forest fires. According to data from global forest watch, Indonesia loss more 25.6 Mha of tree cover from 2001 to 2018. 


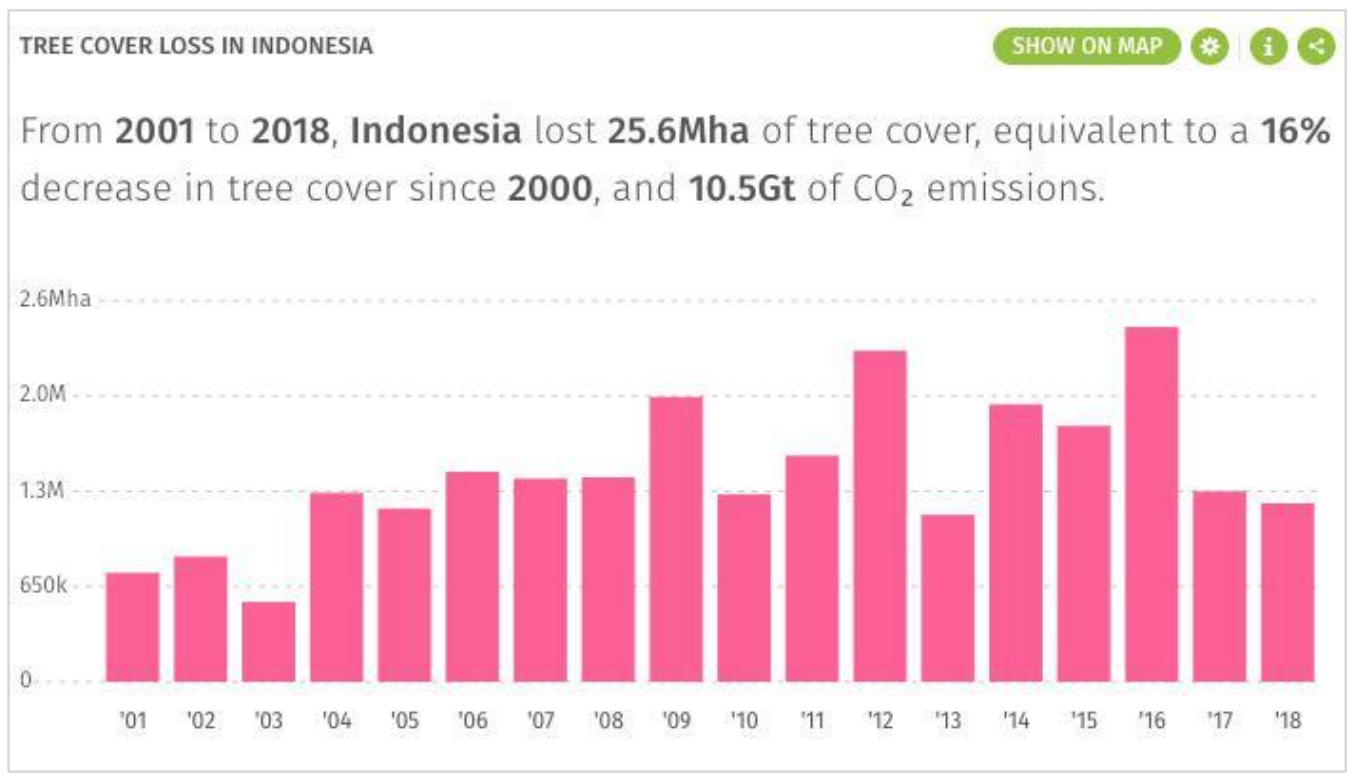

Figure 3 Tree Cover Loss in Indonesia Source: Global Forest Watch, 2020.

Mostly the problem of this loss comes from deforestation, draining peatland, and forest fires. GOI already implement forest moratorium from 2016 until 2017. Eventhough there are already moratorium. The deforestation still happening because the land of clearing for palm oils industry (Wernick, Adam. 2018). Data below was taken on 10 January 2020 from Global Forest Watch that indicate regions or province with the most firer alerts and deforestation alerts in Indonesia.
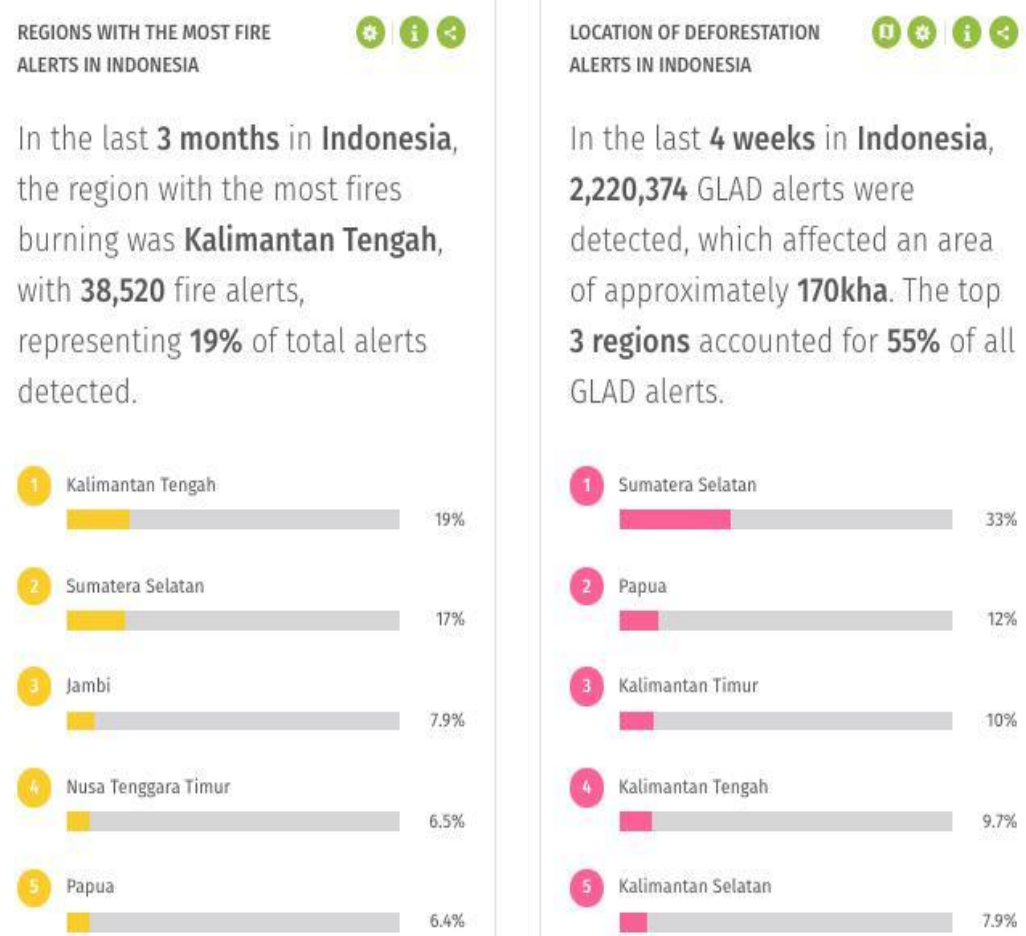

Figure 4 Regions with The Most Fire Alert in Indonesia Source: Global Forest Watch, 2020. 
Mostly areas that have been lost in Borneo and Sumatra due to deforestation and forest fire. This trend showed irregularity because in order to become sources for reducing greenhouse gas emissions, these two regions should be protected. If this situation persists, the progress made by Indonesia in reducing greenhouse gas emissions would fail. Mainly data gathered by researchers come from non-governmental organizations, so GOI should begin to open access to accountability data so that civil society can provide feedback and help monitor the process.

According to Nurdiawansyah, Lindrianasari and Agrianti Komalasari on their journal with title "Carbon Emission Issues in Indonesia". They analyze the factors that affect greenhouse gas emission pollution from the manufacturing industry in Indonesia. As we know, manufacturing industry playing role as well for increasing green gas emission pollution. On their findings. A large company should be pushed to provide the transparency of carbon emission disclosure data. This indicator will help GOI formulating the right policy for greenhouse gas emission reduction (Nurdiwansyah, et al. 2018). It means, the sources of greenhouse gas emission not only coming from forest fires and peatland fires. Manufacturing company take a part for contributing greenhouse gas emission.

Other researcher that concern for green economy coming from Rini Astuti and Andrew McGregor with the title of "Responding to the green economy: how REDD+ and the One Map Initiative are transforming forest governance in Indonesia". Their research findings the messiness of forest governance in Indonesia. This messiness should be transform into more clarity and transparency so internasional carbon investment and forest stakeholder can grasp vividly the current condition on Indonesia's forest governance. REDD+ agency actively developing strategies and technical solutions for entrenched political problems around corruption, power, land rights, poverty, and profit. This action should be monitoring and actively supported so the process for implementing policy for reducing carbon emission can be accomplished.

\section{Conclusion}

Considering the ambition of GOI to implement the UNEP Green Economy through the implementation of greenhouse gas emission reduction targets, a review is still needed. By using an Identification Policy Indicator, we can still track several potential worrying trends. Indonesia still has a problem with implementing the top-down policy. The problem can be seen from a lack of monitoring in the regional sector. An integrated system should be needed to respond quickly to unexpected issues such as a forest fire that will deteriorate the process of integrating Indonesia into the Green Economy.

My finding strengthened by other authors that have research in the carbon emission reduction. The complexity between private sector interest and corruption on goverments official sides resulting inefficient policy on combating carbon emission. The transaparancy of data on forest government should be revealed. Mostly sectors contributing to greenhouse gas emission coming from Land-Use change and forestry.

In order to achieve good results on the greenhouse gas emission reduction program, GOI should implement all policies in a systematic and integrated manner between the central government and 
local government. GOI should involve other actors, such as NGOs or civil society, in support of their objectives. Open access information under real conditions should be prioritized, contributing to the trustworthy participation of stakeholders, the citizens of Indonesia and the global world.

\section{Acknowledgments}

The authors would thank Dr. Surwandono and Dr. Ahmad Sahide at the Department of International Relations, School of Postgraduate Studies, Universitas Muhammadiyah Yogyakarta, Indonesia for their technical Support.

\section{References}

Acharya, Shreekar \& Sequeira, A.H.. (2012). A Model of Green Economy for Developing Countries. SSRN Electronic Journal. 10.2139/ssrn.2192369.

Allen, C., \& Clouth, S. (2012). Green economy, Green growth, and Low-carbon developmenthistory, definitions, and a guide to recent publications. Division for Sustainable Development, Department of Economic and Social Affairs, United Nations, New York, August.Division for Sustainable Development, Department of Economic and Social Affairs, United Nations, New York, August., (1), 1-63.

Bappenas. (2010). Rencana Aksi NasionalPenurunan Emisi Gas Rumah Kaca (RANGRK). Retrieved from https://www.bappenas.go.id/file s/8414/1214/1620/naskah_aka demis.pdf Bappenas. (2012). Langkah Menuju Ekonomi Hijau Sintesa dan Memulainya. 1-58.

Cavanagh, S. (1997). Content analysis: concepts, methods and applications. Nurse Researcher, 4(3), 5-16.

E, Murniningtyas. (2014). Prakarsa
Strategis Pengembangan Green Economy. Deputi Bidang Sumber Daya Alam dan Lingkungan Hidup. Retrieved from https://www.bappenas.go.id/file s/6714/1170/7264/006630_bu ku_green_eco_ap150_2m

uka_17buku.pdf Bidang Sumber Daya Alam dan Lingkungan Hidup.

Global Forest Watch. (2020). Indonesia. Retrieved from https://www.globalforestwatch. org/dashboards/country/IDN

Greisler, David S, Stupak, Ronald J (2007). Handbook of Technology Management in Public Administration. New York: CRC Taylor and Francis.

Morse, J. M. (1991). Qualitative nursing research. Newbury Park, CA: Sage.

Nurdiawansyah, Lindianasari, K. Agriyanto. (2018). Carbon Emission Issues in Indonesia. Retrieved from http://repository.lppm.unila.ac.i d/7178/1/RIBER\%202018\%20 \%28a\%29.pdf

Pearce, D., Markandya, A., Barbier, E. (1989). Blueprint for a Green Economy. In Earthscan.

R. Astuti \& A. McGregor. (2015) Responding to the green economy: how REDD+ and the One Map Initiative are transforming forest governance in Indonesia. Retrieved from https://www.tandfonline.com/d oi/abs/10.1080/01436597.2015 .1082422

Republic of Indonesia. (2016). Indonesia: First Nationally Determined Contribution. Retrieved from http://www4.unfccc.int/ndcregi stry/PublishedDocuments/Indo nesia First/First NDC Indonesia_submitted to UNFCCC Set_November 2016.pdf

Reuters. (2018). Area burned in 2019 
forest fires in Indonesia exceeds 2018 - official. Retrieved from https://www.reuters.com/articl e/us-southeast-asia-haze/areaburned-in-2019-forest-fires-inindonesia-exceeds-2018-officialidUSKBN1X00VU

The World Bank. (2008). Low Carbon Development Options for Indonesia. In Finance. Retrieved from https://sustainabledevelopment. un.org/index.php?page=view\&ty pe $=400 \& n r=850 \&$ menu $=1515$

UNEP. (2008). SCP Indicators for Developing Countries. A Guidance Framework. Paris: UNEP UNEP. (2011). Towards a Green Economy. Pathways to Sustainable Development and Poverty Eradication. Retrieved from https://wedocs.unep.org/handle /20.500.11822/26489

UNEP. (2014). A GUIDANCE MANUAL FOR GREEN ECONOMY INDICATORS. Retrieved from https://www.unpage.org/files/public/contentpage/unep_indicators_ge_for_we b.pdf

Wernick, Adam. (2018). Converting forest into palm oil plantations is 'total devastation' for the planet. Retrieved from https://www.pri.org/stories/20 18-12-28/converting-forestspalm-oil-plantations-totaldevastation-planet

Wijaya, A., H. Chrysolite, M. Ge, et al. (2017). How Can Indonesia Achieve its Climate Change Mitigation Goal? An Analysis of Potential Emissions Reductions from Energy and Land-Use Policies. Retrieved from https://wriindonesia.org/sites/default/files /WRI Layout Paper OCN v7.pdf

World Resources Institute. (2017). Evaluating Indonesia's Progress on its Climate Commitments. Retrieved from https://www.wri.org/blog/2017 /10/evaluating-indonesiasprogress-its-climatecommitments

(C) 2020 by Autors. Submitted for possible open access publication under the terms and conditions of the Creative Commons Attribution (CC BY SA) license (https://creativecommons.org/licenses/by-sa/3.0/). 